\title{
"Water-Colouring" and Geomorphologic Features of the Marl Hills in Changing Quality of Soil and Water
}

\section{Leila Montaseri, Abolghasem Amirahmadi, Mohammadali Zangeneh Asadi, Mokhtar Karami*}

Faculty of Geography and Environmental Sciences, Hakim Sabzevari University, Sabzevar, Iran

Email: L.montaseri@gmail.com, ${ }^{*}$ M.Karami08@yahoo.co.uk

How to cite this paper: Montaseri, L., Amirahmadi, A., Zangeneh Asadi, M. and Karami, M. (2017) "Water-Colouring" and Geomorphologic Features of the Marl Hills in Changing Quality of Soil and Water. Computational Water, Energy, and Environmental Engineering, 6, 129-142.

http://dx.doi.org/10.4236/cweee.2017.61010

Received: November 13, 2016

Accepted: January 22, 2017

Published: January 25, 2017

Copyright $\odot 2017$ by authors and Scientific Research Publishing Inc. This work is licensed under the Creative Commons Attribution International License (CC BY 4.0).

http://creativecommons.org/licenses/by/4.0/

(c) (†) Open Access

\begin{abstract}
Water scarcity has always been one of the most important obstacles in the process of agricultural development in arid and low-rainfall climates. In farming, the water quality also plays an important role; as the poor quality of water can be one of the limiting factors in this sector that in addition to the agricultural problems has also caused soil problems. In this paper, we introduce and study an indigenous method of water conservation and soil protection in the east of Iran termed as "water-colouring" and the role of geomorphologic features of marl hills in one of the rivers located in the southern slopes of the Joghtay Mountain (Kalateh-Sadat Watershed). In this study, field observation, sampling and analysis of water and sediment, physicochemical experiments, SPSS software for statistical analysis and satellite images have been used to produce digital models. Finally, the effects of muddy water and clear water have been compared in terms of chemical quality and productivity of agricultural land. The results show that the method of water-colouring is the best indigenous-economical method for moisture retention and regeneration of the agricultural land soil. Given the statistical reasons and studying the other researches in this field, water-colouring causes change texture and soil composition, fertility of agricultural land and reduce the losses due to evaporation and infiltration.
\end{abstract}

\section{Keywords}

Water-Colouring, Marl Hills, Kalateh-Sadat, Muddy

\section{Introduction}

Water scarcity and drought, especially in the hot and low-rainfall seasons, are one of the inevitable phenomena in Iran. Soil erosion, water loss and contamination of water resources are seen to be due to poor control in both water use and soil use and thus affect our life. Iran, because of its special geographical situation, scattered roughness, 
climate, and the atmospheric fallout, is considered as one of the arid and semi-arid regions of the world. Rainfall in Iran is one-third of the Earth's average rainfall, but the same amount of rainfall also does not enjoy an appropriate distribution in terms of time and place [1]. Drought has caused that the indigenous people seek for problemsolving and finding a solution to reduce the harmful effects of it. Recognition of traditional systems of water resource management that is based on the participation and cooperation of stakeholders may pave the way for planers to newly manage this renewable resource [2]. Soil and water are considered as the most important national resources of each country and sustainable development is achieved by their optimal maintenance and utilization. The relationship between water and soil causes the conservation and protection of each one guarantee the sustainability of the other resource and the waste of one causes a serious threat to the other [3]. Today, the danger of the soil erosion seriously threatens the soils in Iran especially in arid and desert regions [4]. The appropriate management of soil and water resources in arid and semi-arid regions is one of the most important measures to preserve and rehabilitate the fragile environmental conditions of the desert regions that today much attention is paid to it, because by implementing proper managerial measures we can create the background of sustainable development, prosperity and economic development in these areas [5]. One of the manifestations of the erosion process in the arid regions is the wind erosion [6]. Wind erosions are usually associated with dryness of air and its rate increases due to loss of soil moisture [7]. In general, the results of researches have shown that with continuation of wind erosion, all lands with different usages go ahead toward siltation and the adhesion rate of soils is reduced more by passing of time that this fact, in addition to the changing of most of soil properties, causes the soil fertility and increases the rate of erosion and with continuation of drought and wind erosion, the problems in arid and semi-arid areas are worsened [8]. Recent studies show that the agricultural lands lose their fertility after a period. Therefore, the use of effective ways for decreasing the speed of this process, reducing energy consumption, and lowering of the water erosion and the wind erosion seems favourable.

The present study was done to investigate one of the traditional methods used by local people of Kalateh-Sadat village located in Sabzevar in Khorasan Razavi province in the east of Iran that is known as "water-colouring" in local terms. Using marl hills existing in the region as a geomorphologic feature, farmers make muddy the river water in order to muddy water with marl reaches the downstream agricultural lands. In this study, we seek to find out whether this traditional method is actually a useful one or not. Can this method be an effective way to protect soil and water and to reduce the devastating effects of erosion and degradation of soil and water resources in this region? Is there a relationship between this method and increasing the capacity of soil moisture?

In recent years, the tendency for retrieval of the traditional knowledge of soil management to be combined with modern methods of soil preservation has increased [9]. In semi-arid region of Lessi in the northwest of China, sand and gravel are used as mulch. The history of this traditional method dates back to the era of Ching dynasty about 3000 years ago. The mulch of sand and gravel or sand alone causes the preserva- 
tion of the rare water, the change of hydrologic process, improvement of soil fertility, reduction of evaporation and runoff, saving in soil and water usage, improvement of water infiltration and soil temperature, control of wind and water erosion and increase of biologic activities and soil fertility. However, by development of modern activities, this traditional method is changing and neglecting [10]. Also, on the sediment-producing of marls, some studies have been done by Benito et al. (1991) [11] in Spain, England (1971) [12] in South Dakota in America, Buffalo and Nehon (1992) [13] in France that their results show the strict sensitivity of marls to erosion. The history of the indigenous ways of soil and water management in the world, including Iran, reaches to 3 to 5 thousand years ago. Despite the development of modern methods, these methods are still effective in different areas [14]. Iran is one of the oldest parts of the world where there have been good standards and rules for the use of water and land resources long ago, and anywhere in this land, the traditional operation management of water resources has existed according to the climatic, social, and cultural conditions and agricultural customs [15]. In Iron Duke Mine at Glendale in Zimbabwe, there are pools coating with clay. The condensed clay layers are usually used as a cover to limit the penetration of drainage of the mine acid to surrounding environment from controlling areas or the pool and to prevent the transmission of acidity contamination to the groundwater and surrounding soil [16]. We can minimize the loss of water penetration from constructed wetlands, wildlife refuges, drainage wetlands, runoff collection ponds and other levels of engineering tankage or water ecosystems with deep groundwater levels by artificial liners (plastic, compacted land, etc.) or with natural processes such as accumulation of sediment, chemical and microbiological processes. Sediment accumulation can be increased by adding slurry of soil or muddy water. This will create a layered coverage that has the most control over penetration. In addition, adding sodium carbonate in water reduces the penetration of water as much as possible [17]. Amrani Paza (1998) [18] in a research on southeast watershed of Granada in Spain, by analyzing 171 specimens taken from neogen contracted soil from the southeast edge of Granada watershed and doing standard tests of soil classification for engineering objectives concluded that marl is appropriate as the bed in dams due to its flexibility, high content of carbon and geotechnical properties. Some researchers have studied the role of the chemical properties in infiltration process of water in soil. Oster and Shinberg (2001) [19] as well as Halliwell et al. (2001) [20] demonstrated that high levels of sodium solution reduce the water infiltration rates in soil by reducing aggregate stability, dispersing the particles and inflammation of expansible clays. They also believe that this damaging effect is reduced in the presence of lime and gypsum. Sodium has devastating effects on soil permeability such that reduces water infiltration by creating and developing the superficial crust and dispersion of particles [21]. In contrast, factors such as calcium have desirable effects on permeability [22].

Ajwa and Trout (2006) [22] reported that increasing of fine clay and silt particles reduces the permeability of the soil. Schleiss et al. (2008) [23] by studying three reservoir dams in mountainous regions of Swiss found that the muddy flow was the most important factor in speeding up the sedimentation in these reservoirs. Withworth and Ghazifard (2009) [24] in a research entitled "the membrane effects in clay-lined inward gra- 
dient landfills" refer to this subject that in the ditches of burial place of sweepings for controlling the transfer of pollution outward and underground waters, people cover the internal slope of the cavity with clay that this coverage acts as the semi-osmosis membrane. Tekwa et al. (2010) [25] in a research on six villages of Mobi region in Adamava State in Nigeria recorded the local techniques of water and soil preservation in a certain time period and tested them with Likert scale. The results showed that the indigenous techniques considerably protect soils against erosive damages and the possibility of optimal preservation of a food product in this region is plausible through local effective methods. Mashir and Kedra (2012) [26] in a study under the title of "soil and water preservation through indigenous management and traditional methods in Ethiopia based on sampling from four mountainous regions and 120 farmer families and recording the local and traditional methods used" found that recognition of traditional and local methods of soil preservation can be effective for social and cultural evaluation and limitations of economical system. Abedini and Khani (2011) [27] in investigation of making muddy the water of Ferdows aqueduct ${ }^{1}$ by the qualitative and quantitative parameters of water studied the effect of making muddy the water on the amount of water and its effect on soil and agricultural products and the changing of water nature. The samples taken (before and after making muddy the water) as well as the saturated sample taken from the soil used for making muddy the water were tested to determine the qualitative parameters using standard methods, and Wilcox and Schuler samples were prepared. Eventually we came to the conclusion that after making muddy the water, it did not changed harmfully, its electrical conductivity did not increase significantly, and we face with the increase of the useful minerals for the plant, however, lower than the non-allowed limit and that making muddy the water does not hurt parameters required for agricultural water. Also, this process does not create any obstacle in terms of water quality parameters for drinking.

The study area is located between two east longitudes of $57^{\circ} 05^{\prime} 39^{\prime \prime}$ and $31^{\circ} 16^{\prime} 57^{\prime \prime}$ to north latitudes of $36^{\circ} 13^{\prime} 59^{\prime \prime}$ and $36^{\circ} 26^{\prime} 12^{\prime \prime}$ with an area of 95.83 square kilometers. In terms of political situation, this watershed belongs to Davarzan district of Sabzevar city in Khorasan Razavi province in east of Iran. Figure 1 shows the geographical location of Kalateh-Sadat watershed.

\section{Research Methods and Process}

At first, the study area was identified and the limits of Kalateh-Sadat watershed and agricultural lands were determined on the topographic map. Then, to determine the quality of drinking and agricultural water the topographic maps, satellite images, geological maps, library studies, field observation and interviews with local farmers, sampling and analysis of water and sediment specimens and testes to determine the $\mathrm{pH}, \mathrm{EC}$, complexometery, flame photometry, spectrometry, granolometery, calcimetry, and Schuler $\&$ Wilcox charts were used. Finally, the accuracy of all laboratory results was tested and

${ }^{1}$ In Baladeh aqueduct in Ferdows located in Khorasan Razavi that its history dates back to per-Islam and Sassanid period, based on an old custom the water is made muddy using the clay existing in the region by individuals that are known as Tiregar (person who makes the water muddy) to reduce water loss due to its penetration in the path and also decrease the rate of water evaporation [27]. 


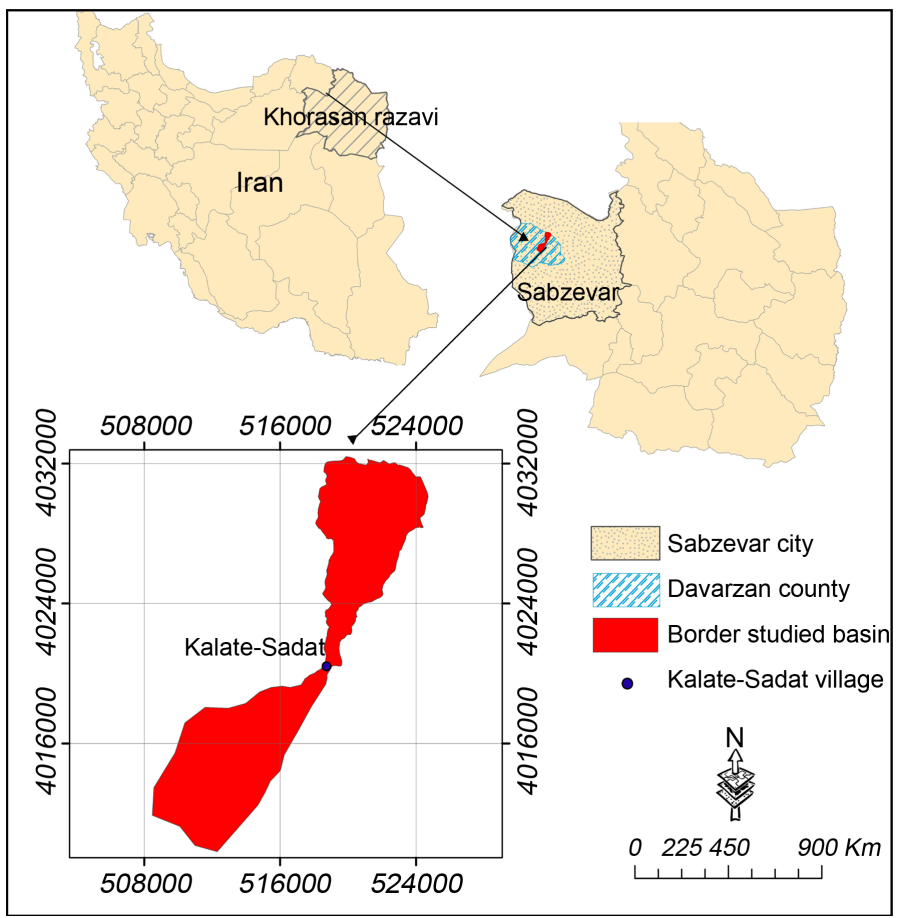

Figure 1. The geographical location of Kalateh-Sadat watershed (Source: the authors).

analyzed by SPSS software and for this purpose, Excell, Arc GIS, and SPSS softwares were used to analyze data. In granulometry and calcimetry, the frequency of sediment materials in various drops and the percent of sediment lime were determined for analysis of soil mechanics. To determine the concentrations of the two ions of calcium and magnesium, complexometery or titration was used. The concentrations of sodium, potassium and ferrous were determined using flame photometry and spectrometry. Also, $\mathrm{pH}$ and electrical conductivity (EC) of the specimens were measured in terms of micromohus per centimeter with conductivity meter at temperature of $25^{\circ}$ centigrade. Sodium absorption ratio (SAR) and also solution sodium percent (SSP) were calculated from the following equations:

$$
\begin{gathered}
\mathrm{SAR}=\mathrm{Na}^{+} / \sqrt{\left(0.5 \times\left(\mathrm{Ca}^{++}+\mathrm{Mg}^{++}\right)\right)} \\
\mathrm{SSP}=\mathrm{Na}^{+} /\left(\mathrm{Ca}^{++}+\mathrm{Mg}^{++}+\mathrm{Na}^{+}+\mathrm{K}^{+}\right) \times 100
\end{gathered}
$$

All amounts of cations in the above equations are based on meq/lit [28].

Finally, Schuler and Wilcox diagrams were prepared to determine the quality of drinking and agricultural water respectively. Then, accuracy verifications of all experimental results were tested in SPSS software through Pearson correlation coefficient and Mann-Whitney test.

\section{Results and Discussion}

The main geomorphologic feature in Kalateh-Sadat watershed is "marl hills" in KalatehSadat village and the impact of these marls on water and soil of downstream agricultural lands. The rate of the elements percent in marl can be effective in improvement or 
weakening of the soil texture, soil compositions, and the agricultural products in a region. Since Kalateh-Sadat village is located on fans and its downstream lands are located on the floodplain, therefore its specific geomorphologic features can be effective on agricultural activities, especially its irrigation. Desert streams are the cause of dry winds and exacerbation of soil erosion in the region. Strong winds affect the downstream lands and take away fine and soft soil with, the sand remains in place; this leads to soil erosion and degradation of soil texture, especially in the agricultural lands, and therefore moisture is kept in the soil and quickly penetrates in coarse-aggregate soil. With the beginning of spring and increasing of the temperature, most plants begin their growth and activity, but sometimes water shortage disrupts normal growth of the plant; therefore, we should take advantage of the least available water using different ways and prevent water loss in order the limited water be available to plants for more time. So, in order to maintain soil moisture, we should repair the fine-textured soil with coarsetextured soil in order this becomes possible with small particles of colloidal marl.

Water-colouring or making muddy the water in Kalateh-Sadat River upstream with marls in the hills of Kalateh-Sadat village that is done by a resident of the village in order the water impregnated with fine and brick-colour marls reaches to the downstream of the river and irrigates the farm lands of the region. This procedure is done by separating a branch of the main river at upstream and turning it on the marl hills and moving water over the lines of balance curve and creating grooves on these curved lines once every few hours in direction of the slope in the warm and low-rainfall seasons from April to October by a person known as "paint sprayer". water of river, due to marl particles is made muddy and the muddy water penetrates in the bottom of the riverbed and farmlands, and fills the pores and creates a layer with low permeability and in arable lands with putting together soil particles causes soil adhesion and water and soil conservation against the high temperature and winds of the region.

After field observation of the marl hills, the location of the "water-colouring" operation, and the place of incorporation of clear water and muddy water and fields irrigated by muddy water that are shown in Figure 2, the water samples were taken from 7 points whose characteristics are presented in Table 1 . Then, the specimens were transported to the laboratory and $\mathrm{pH}, \mathrm{EC}$, total hardness, calcium, magnesium, sodium, potassium, ferrous and sediment percent of each sample were analyzed. The locations of the water samples taken in the area of Kalateh-Sadat watershed have been shown in Figure 3.

Total hardness of water and hardness of calcium and magnesium of the samples was measured in the chemistry laboratory in terms of milligrams per liter of calcium carbonate by complexometery test. Complexometery test (titration) showed that muddy sample No. 1 and clear samples No. 2, 3 and 6 are hard water and enjoy good hardness, and muddy samples No. 4, 5 and 7 are very hard water. In other words, the concentrations of calcium and magnesium in muddy water samples were more than clear water samples. Based on the flame-photometry test, the amounts of sodium and potassium in the muddy samples No. 4, 5, and 7 were more than in other specimens (but were not at the critical and vulnerable levels). Spectrometry test and determination of the amount of ferrous showed that in muddy water sample No. 7 which is in the place of the agricultural 

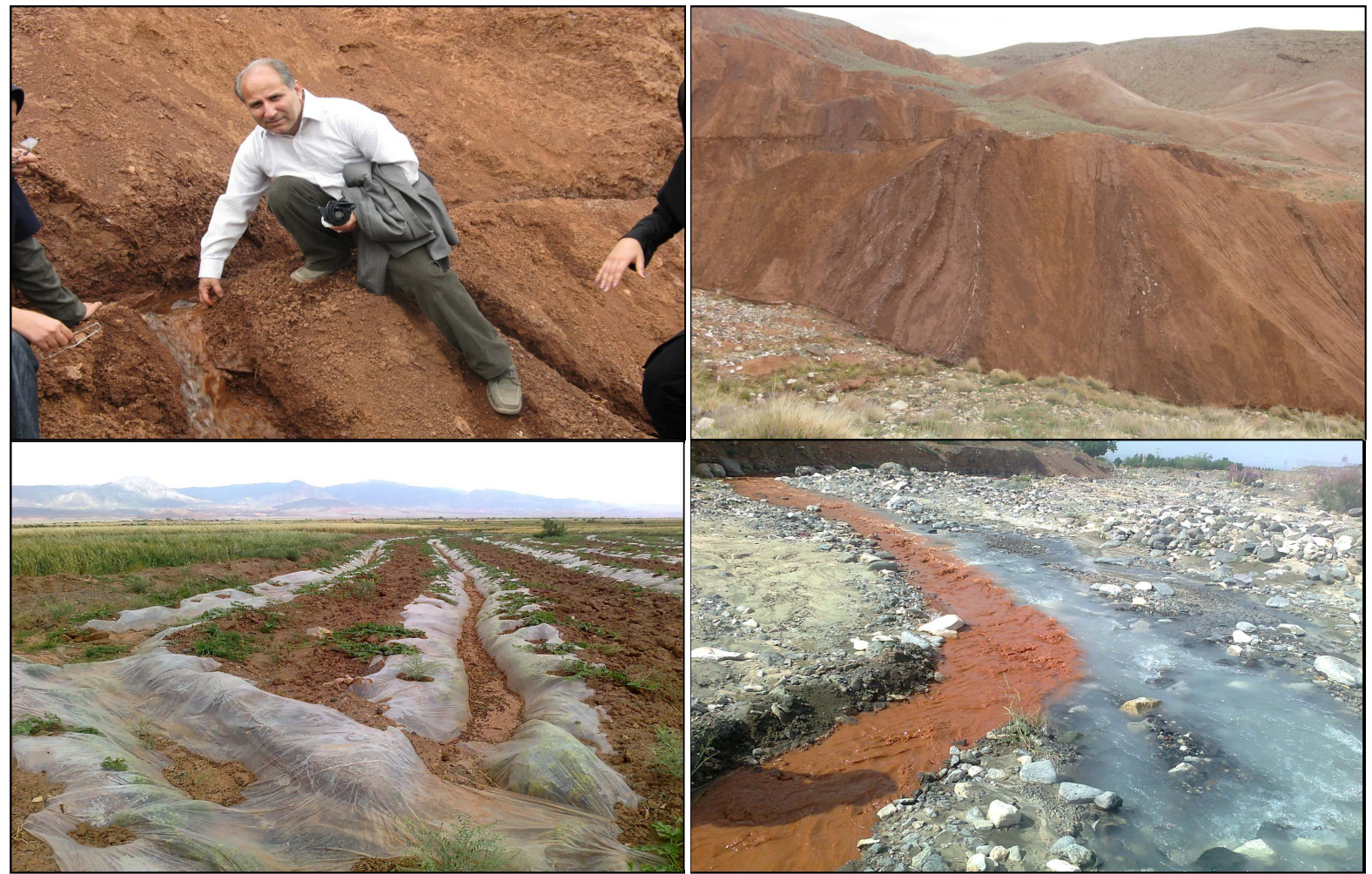

Figure 2. Above: Neogene marl hills (right), the location of the water-colouring operation (left); below: the place of incorporation of clear water and muddy water (right), farms at downstream of the watershed and brick-colour surface of the soil (left). (Source: authors).

Table 1. The geographical details of location of taking water samples from Kalateh-Sadat River. (Source: authors).

\begin{tabular}{|c|c|c|c|c|}
\hline Number of sample & Apparent specifications & $\begin{array}{l}\text { Height } \\
(\mathrm{m})\end{array}$ & $\begin{array}{l}\text { Latitude } \\
\text { (UTM) }\end{array}$ & $\begin{array}{l}\text { Longitude } \\
\text { (UTM) }\end{array}$ \\
\hline 1 & $\begin{array}{c}{ }^{*} \text { Muddy water, after incorporation, entering into } \\
\text { the fields of Kalateh-Sadat }\end{array}$ & 1210 & $4,020,076$ & 518,484 \\
\hline 2 & $\begin{array}{l}\text { Clear water, before being muddy, as the main } \\
\text { branch }\end{array}$ & 1231 & $4,020,616$ & 518,838 \\
\hline 3 & Clear water, the main branch, at the marl hills & 1258 & $4,020,821$ & 519,086 \\
\hline 4 & $\begin{array}{l}\text { Muddy water, at the marl hills and source of } \\
\text { making muddy }\end{array}$ & 1252 & $4,020,791$ & 519,160 \\
\hline 5 & Muddy water, shortly before incorporation place & 1225 & $4,020,514$ & 518,816 \\
\hline 6 & Clear water, shortly before incorporation place & 1222 & $4,020,517$ & 518,815 \\
\hline 7 & $\begin{array}{c}\text { Muddy water, after incorporation, Koshk Bagh } \\
\text { Village, downstream fields }\end{array}$ & 971 & $4,013,443$ & 511,688 \\
\hline
\end{tabular}

${ }^{*}$ In fact, samples 1, 4, 5 and 7 were target examples of our research and samples 2, 3 and 6 were selected as control group.

lands, the ferrous concentration is higher. The $\mathrm{pH}$ of samples due to the presence of alkaline elements (sodium, potassium, etc.) and alkaline earth elements (calcium, magnesium, etc.) goes more towards alkalinity; in other words, the $\mathrm{pH}$ of samples of water taken from Kalateh-Sadat River is in enough alkaline level and desirable for use and there is no difference between clear and muddy water samples. The electrical conductivity 


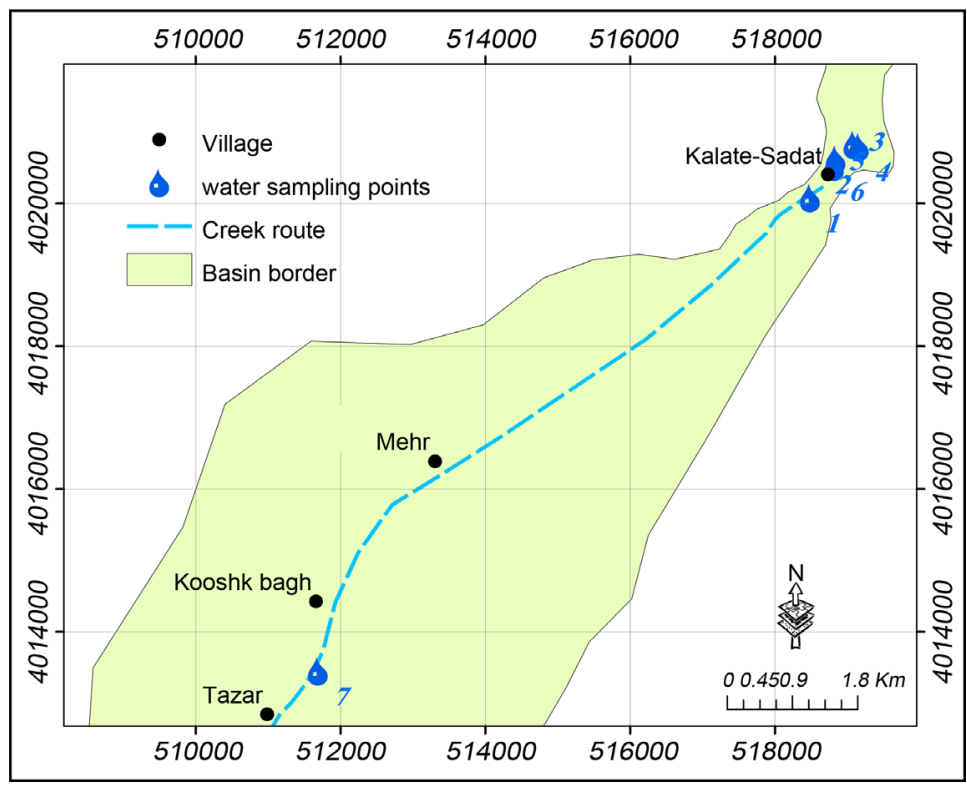

Figure 3. Location of taking water samples from Kalateh-Sadat watershed. (Source: authors).

(EC) of the samples was measured in terms of $\mu \mathrm{mh} / \mathrm{cm}$ at $25^{\circ} \mathrm{C}$ by conductivity meter. After the EC test, according to Wilcox classification ${ }^{2}$, the salinity of samples 1, 2, 3, 5, 6 was evaluated at the medium level and the salinity of samples 4 and 7 at high level.

According to $\mathrm{SAR}^{3}$ and $\mathrm{SSP}^{4}$ classification, all specimens are at very good conditions and there is low sodium in the samples. Calculation the rate of percent and concentration of sediment in the taken water samples showed that the maximum of sediment percent is related to the sample No. 4 which is located in a muddy source and the minimum of sediment percent is related to samples 2 and 3 which are located in the main branches of clear water. In other words, the increasing of sediment percent causes the increasing of muddiness and vice versa. Since, the suspended materials change the color of water and make it muddy, the concentration of suspended materials is called muddiness that is shown in milligrams or grams per liter. The results of tests carried out on water samples taken from Kalateh-Sadat River have been presented in Table 2.

Today, the water quality studies have a wide range and include the issues related to the contamination of groundwater and surface water. Therefore, in hydrology studies, along with the quantitative studies of water, its qualitative standards are also investigated [29]. A part of the quality of groundwater and surface water is related to precipitation, but the type of geological formations, the length of passed course and duration of this displacement play the most important role. Concentration of the materials in the water, although in low amounts, plays an important role in the use of the water in drinking, agriculture, and industry. Water-soluble salts affect on the growth of plants and change soil characteristics. Depending on the type of water use, we can follow specific ${ }^{2}$ Wilcox classification: low (100 - 250), medium (250 - 750), high (750 - 2250), very high (>2250) [29]. ${ }^{3}$ The relationship of the rate of sodium existing in water and SAR has been defined as follows: low sodium $(10>$ SAR $>0)$, average sodium $(18>$ SAR $>10)$, high sodium $(26>$ SAR $>18)$, very high sodium $($ SAR $>26)$ [28].

${ }^{4}$ In terms of SSP, waters are classified as five groups: excellent $($ SSP $<20)$, good $(40>$ SSP $>20)$, acceptable $(60>$ SSP $>40)$, suspicious $(80>$ SSP $>60)$, bad $($ SSP $>80)$ [29]. 
goals in determining water quality. Water which has not good quality for drinking may be diagnosed good for farming [28].

After the quantitative measurement of elements existing in the water sample of the river and calculation of required parameters, we examined its quality for drinking and irrigation uses. According to Schuler's chart, the quality of Kalateh-Sadat River's water for drinking is at optimal condition and even its total hardness is in good condition. Wilcox diagram also shows that water samples No. 1, 2, 3, 5 and 6 are as good water samples, and samples No. 4 and 7 are the average water samples for irrigation of agricultural lands. Schuler \& Wilcox charts are shown in Figure 4.

Table 2. The results of physicochemical tests on water samples taken from Kalateh-Sadat River. (Source: authors).

\begin{tabular}{|c|c|c|c|c|c|c|c|c|c|c|c|}
\hline \multirow{2}{*}{$\begin{array}{l}\text { Number } \\
\text { of sample }\end{array}$} & \multicolumn{3}{|c|}{$\mathrm{ml} /$ lit $\mathrm{CaCO}_{3}$} & \multicolumn{3}{|c|}{$\mathrm{ml} / \mathrm{lit}$} & \multicolumn{2}{|r|}{$\mu \cdot \mathrm{mhos} / \mathrm{cm}$} & \multicolumn{2}{|c|}{ meq/lit } & \multirow{2}{*}{$\begin{array}{l}\text { Sediment } \\
\text { percent }\end{array}$} \\
\hline & Total hardness & $\begin{array}{c}\mathrm{Ca} \\
\text { Hardness }\end{array}$ & $\begin{array}{c}\mathrm{Mg} \\
\text { Hardness }\end{array}$ & $\mathrm{Na}$ & K & $\mathrm{Fe}$ & $\mathrm{pH}$ & Ec & SAR & SSP & \\
\hline 1 & 164.0 & 40.0 & 124.0 & 0.21 & 0.006 & 0.012 & 7.89 & 552.0 & 0.007 & 0.272 & 0.27 \\
\hline 2 & 164.0 & 48.0 & 116.0 & 0.16 & 0.002 & 0.024 & 8.07 & 499.0 & 0.005 & 0.206 & 0.00 \\
\hline 3 & 150.0 & 32.0 & 118.0 & 0.17 & 0.001 & 0.007 & 7.70 & 502.0 & 0.006 & 0.248 & 0.00 \\
\hline 4 & 240.0 & 76.0 & 164.0 & 0.34 & 0.012 & 0.027 & 7.71 & 769.0 & 0.010 & 0.308 & 2.12 \\
\hline 5 & 220.0 & 68.0 & 152.0 & 0.31 & 0.008 & 0.009 & 7.91 & 668.0 & 0.009 & 0.307 & 1.08 \\
\hline 6 & 156.0 & 28.0 & 128.0 & 0.12 & 0.010 & 0.034 & 8.00 & 511.0 & 0.004 & 0.167 & 0.01 \\
\hline 7 & 210.0 & 60.0 & 150.0 & 0.50 & 0.010 & 0.037 & 7.77 & 998.0 & 0.015 & 0.509 & 0.14 \\
\hline
\end{tabular}

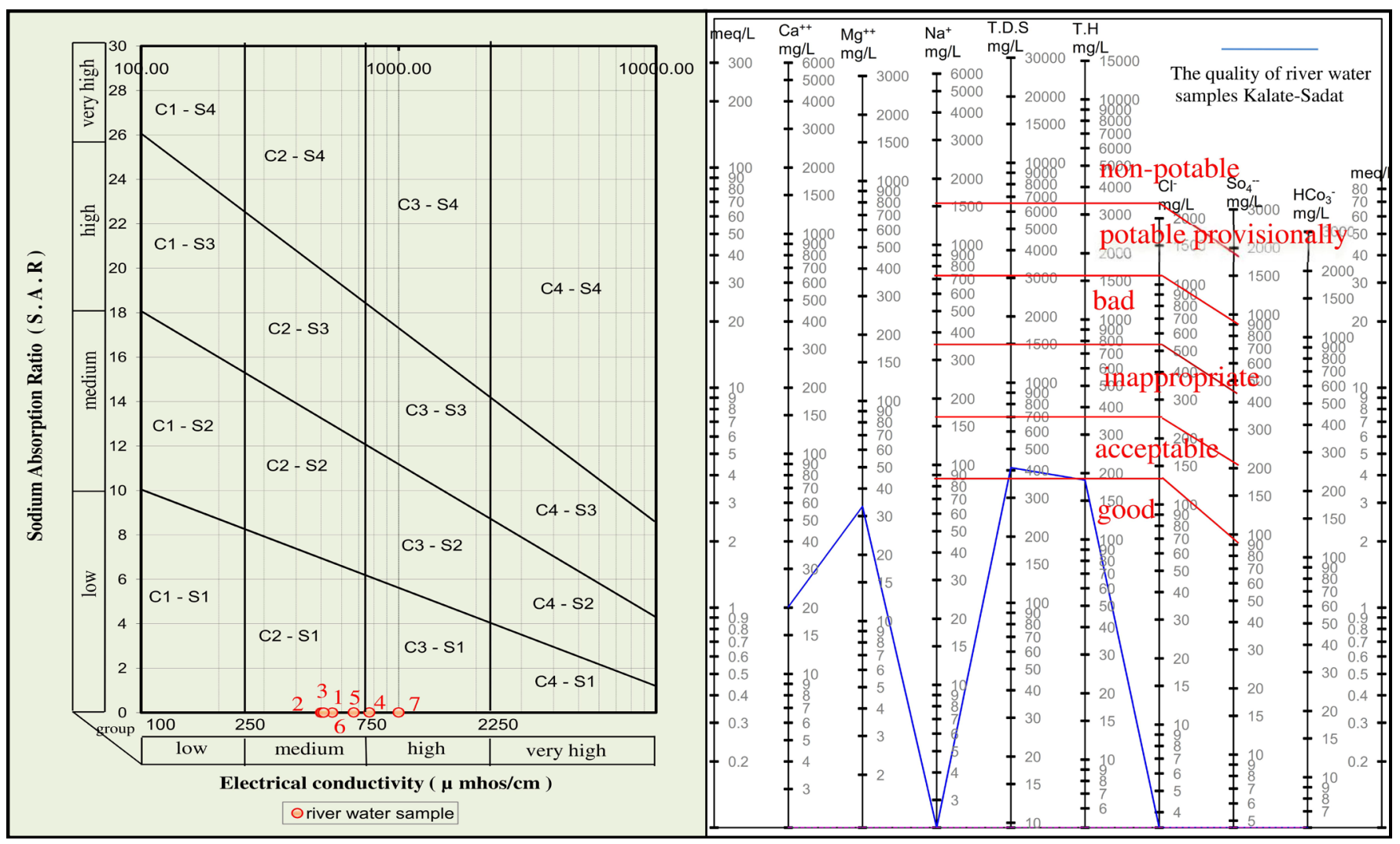

Figure 4. Schuler's chart (right), Wilcox's chart (left). (Source: authors). 
After the experimental results from different tests on Kalateh-Sadat water samples, examining their impacts on each other and on the whole is obvious. Accordingly, these questions rise: Is there any relationship between the rate of sediment percent and key variables of water quality? Can muddiness affect the fundamental variables of water quality? Therefore, the relationship between the rate of sediment and the $\mathrm{EC}, \mathrm{pH}, \mathrm{TH}$, SSP and SAR and also the impact of muddiness on water quality were analyzed by SPSS software. At first, we studied the descriptive statistics and frequency, frequency percent and cumulative percent and histogram distribution of data. Then the means of chemical variables in clear water and muddy water were compared that its diagram is shown in Figure 5.

Since our data are quantitative and numerical, the relationship between them was assessed by Pearson correlation coefficient. Therefore, the Pearson correlation coefficient relationship between the rate of sediment percent and quality variables of water (EC, $\mathrm{pH}, \mathrm{TH}, \mathrm{SSP}$ and SAR) showed a significant linear relationship in direction direct $(\mathrm{r}=0.84)$ and at the error level of 0.05 with total hardness variable $(\mathrm{P}$-value $<0.05)$. In order to be sure about the lack of correlation between the amount of sediment and other variables, the remote data were deleted and their correlation coefficient were

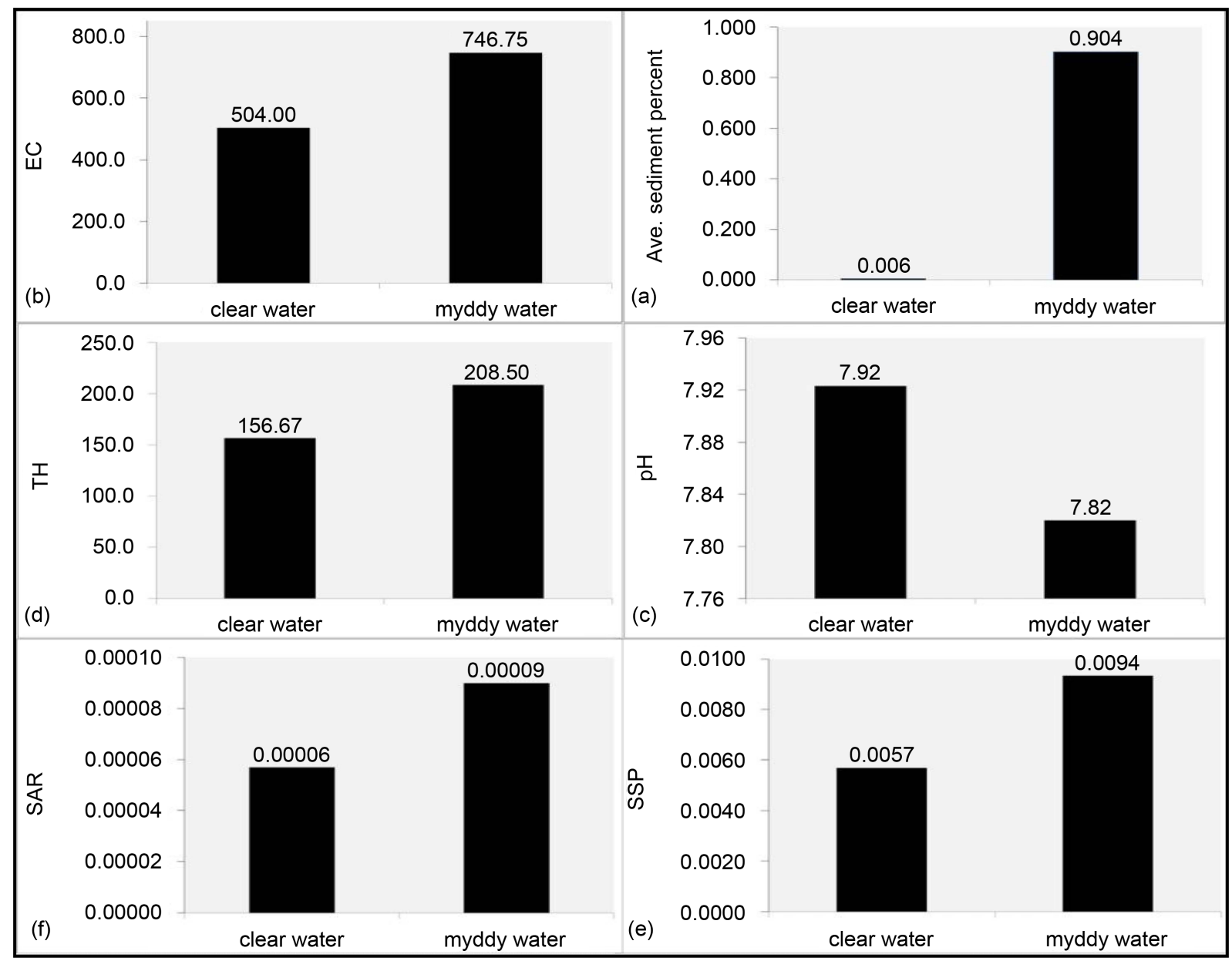

Figure 5. Comparison of chemical variables in clear water and muddy water of Kalateh-Sadat river; (a) Average sediment percent, (b) Electrical conductivity, (c) Acidity, (d) Total hardness, (e) Soluble sodium percentage, and (f) Sodium adsorption ratio. (Source: authors). 
re-assessed, which in this case, a significant direct relationship was found between the amount of sediment and EC and at error level of $0.01(\mathrm{r}=0.99$; P-value $<0.05)$. In other words, the increase or decrease of the rate of sediment or muddiness of water affect on the total hardness, the electrical conductivity and salinity of water. About the other variables, there is no any linear relationship between them and the rate of sediment percent $(\mathrm{P}$-value $>0.05)$ and this means that muddiness does not have any role in their increasing or decreasing. The results of the tests are provided in Table 3.

To compare the effect of muddiness on water quality, Mann-Whitney test was used. The results of Mann-Whitney test and comparison of distribution of fundamental variables of water quality (EC, $\mathrm{pH}, \mathrm{TH}, \mathrm{SSP}, \mathrm{SAR}$ and sediment percent) for clear water and muddy water showed that only the distribution of sediment percent, electrical conductivity and total hardness differ significantly (P-value $<0.05)$, and there is no difference in the rest of the variables (P-value $>0.05)$. In other words, we can say that the muddiness has been effective on the rate of distribution of sediment percent, electrical conductivity and total hardness of water, and the rest of the variables have not been significantly changed by muddiness. Test results are presented in Table 4.

\section{Conclusions}

The results of tests and their statistical analysis showed that the muddiness has affected on the total hardness (concentration of calcium and magnesium) and water salinity. The amount of sodium and potassium in the muddy water is higher than clear water, but according to the results of the SSP and SAR in the Mann-Whitney test and correlation coefficient, their increase and impact are not significant and critical. Sodium and potassium existing in the particles of marl cause the separation and distribution of soil particles and filling the pores, reduction of porosity and permeability, and also weakness of the gravity force in directing the water; therefore moisture remains longer in the plant. Also the existence of calcium and magnesium causes the coagulation of many of the clay and humus colloids and increases the soil adhesion and its resistance against wind erosion by preserving its moisture and restoring its coarse texture. On the other hand, an increase in cations of sodium, potassium, magnesium, and calcium in the muddy water increases the cation exchange capacity (C.E.C), chemical activity of the soil and the increased percent basic saturation (P.B.S) of cations in soil which represents the fertility and sufficient nutrient materials of the soil. By investigation of the $\mathrm{pH}$ results of

Table 3. The results of the pearson correlation coefficient between the rate of sediment percent and water quality variables. (Source: authors).

\begin{tabular}{ccccccc}
\hline & EC & pH & TH & SSP & SAR & EC (repeat) \\
\hline $\mathbf{r}$ & 0.35 & 0.40 & $0.84^{*}$ & 0.30 & 0.34 & $0.99^{*}$ \\
P-value & 0.43 & 0.36 & 0.01 & 0.50 & 0.44 & 0.00 \\
\hline
\end{tabular}

Table 4. The results of the Mann-Whitney test in clear water and muddy water. (Source: authors).

\begin{tabular}{ccccccc}
\hline & Sediment percent & EC & pH & TH & SSP & SAR \\
\hline P-value & 0.03 & 0.03 & 0.48 & 0.05 & 0.48 & 0.46 \\
\hline
\end{tabular}


water samples as well as that of sample No. 7, it was found that the muddiness of water has no effect on $\mathrm{pH}$ and "water-colouring" technique does not change the alkalinity of the soil. Because of the climate of the region, the leaching process has a limited performance; therefore, the dissolution and transfer of the marl particles are slowed down and consequently the marl colloids remain in soil, the resilience of soil is preserved and permeability and porosity are relatively kept down in order to water maintain longer for the plant and its loss is reduced. Basic cations still persist in the soil and soil fertility is maintained. According to Schuler and Wilcox's charts and classification of SSP and SAR, the quality of drinking and agricultural water of Kalateh-Sadat River and even its total hardness is in the ideal condition, and sodium found in the samples is low. So, "water-colouring" causes the fertility of agricultural lands and restoration of soil texture by keeping the alkalinity of the soil, and it can be a natural and effective factor for conservation of water and soil in arid and low-rainfall regions. So the existence of marl hills in the region is optimal to reduce the negative effects of wind and water erosion by increasing the soil adherence for water and soil preservation as a strategy, even if this may be a traditional strategy.

This method can be done in regions with a similar climate of this studied basin. Therefore, it is appropriate that this study is done with more samples in the certain period of time. Also, maybe this method can be an integrated natural model of geology, geomorphology, pedology and hydrology and the same name can be recorded in the science of geomorphology.

\section{Acknowledgements}

The authors of this paper are interested to acknowledge the soil laboratory personnel of School of Geography and Environmental Sciences and the chemistry laboratory personnel of Department of Chemistry at Hakim Sabzevari University, and the contamination laboratory personnel of Public Health School of Sabzevar Medical Sciences, who intimately helped us in performing the tests.

\section{References}

[1] Vahhabi, J. (2003) Analysis of Systems of Flood Distribution and Introduction of Research Requirements. Journal of Research and Construction in Natural Resources, 16, 22-29.

[2] Sheikhi, D. (2011) Management of Water and Repair and Maintenance of Buildings in Traditional System of Water Management in Rural Regions (Case Study: Shara Plain in Markazi Province). International Conference of Traditional Knowledge of Water Resources, Yazd.

[3] Zangane Asadi, M. and Karimidost, A. (2010) The Quantitative Models of Evaluating Water Erosion. Tarbiat Moalem University, Sabzevar.

[4] Banj Shafiei, S.H. (2010) The Study of the Effect of Polymer Mixture with Fine Sand to Revitalize Desert Soils in Terms of Hydrology to Prevent Erosion. 2nd National Conference on Wind Erosion, The Scientific Association of Management and Control of Desert Regions of Iran, Yazd.

[5] Javadi, M. (2009) Evaluation of Managerial Measures Applied in Controlling Desert Conditions in Mahan Watershed. 5 th National Conference of Iranian Sciences and Engineering in Watershed and Hydrology Affairs, Iranian Association of Watershed and Hydrology, Karaj.

[6] Yamani, M. and Karami, F. (2010) Dominant Processes in Morphologic Formation and 
Change of Sand Masses of Khozestan Plain (Case Study: The Gravel of the North of Ahwaz). Journal of Geographical Studies on Arid Regions, 1, 25-42.

[7] Naderi, F., Karimi, H., Alimoradi, S. and Naseri, B. (2012) Assessment of the Intensity of Wind Erosion in Changoleh Plain in Ilam Province by Empirical Method of IRIFR.E.A. 1 st National Conference on Desert, International Research Center of Tehran University.

[8] Soloki, H., Khameh Cheian, M., Hafezi Moghadas, N. and Alavi Panah, K. (2009) The Study of Wind Erosion in Sistan Plain and Its Effects on Engineering Properties of Soils. Journal of Iranian Geology Association, 2, 13-26.

[9] Dotterweich, M. (2013) The History of Human-Induced Soil Erosion: Geomorphic Legacies, Early Descriptions and Research, and the Development of Soil Conservation-A Global Synopsis.

[10] Li, X.Y. (2003) Gravel-Sand Mulch for Soil and Water Conservation in the Semiarid Loess Region of Northwest China. Catena, 52, 105-127. https://doi.org/10.1016/S0341-8162(02)00181-9

[11] Benito, G., Gutierrez, M. and Sancho, C. (1991) Erosion Pattern in Rill and Interrill Areas in Badland Zones of the Middle Ebro Basin (NE-Spain). In: Soil Erosion Studies in Spain, 41-54.

[12] Engelend, G.B. (1971) Runoff Process and Slope Development in Badland National Moment South Dakota. Journal of Hydrology, 18, 55-79. https://doi.org/10.1016/0022-1694(73)90025-5

[13] Bufalo, M. and Nahon, D. (1992) Erosional Process and Mediterranean Badlands: A New Erosivity Index for Predicting Sediment Yield from Gully Erosion. Geoderma, 52, 133-147. https://doi.org/10.1016/0016-7061(92)90079-M

[14] Bashari, M., Kavoosi, M. and Delfaredi, S. (2012) The Traditional Methods of Obtaining Precipitation Water in Sistan and Baluchistan Province. 1st National Conference on Precipitation Submergible Surface Systems, Mashhad.

[15] Fallah Rastegar, A., Yoosefi, M. and Hezarkhani, M. (2011) The Role of Traditional and Modern Management of Water in Planning Processes, Construction and Utilization of Irritation and Drainage Systems. International Conference on Indigenous Knowledge of Management of Water Resources, Yazd.

[16] Mapanda, F., Nyamadzawo, G., Nyamangara, J. and Wuta, M. (2007) Effects of Discharging Acid-Mine Drainage into Evaporation Ponds Lined with Clay on Chemical Quality of the Surrounding Soil and Water. Physics and Chemistry of the Earth, 32, 1366-1375. https://doi.org/10.1016/j.pce.2007.07.041

[17] Bouwer, H., Ludke, J. and CRice, R. (2001) Sealing Pond Bottoms with Muddy Water. Ecological Engineering, 18, 233-238. https://doi.org/10.1016/S0925-8574(01)00071-4

[18] Amrani Paaza, N.E., Lamas, F., Irigaray, C. and Chacon, J. (1998) Engineering Geological Characterization of Neogene Marls in the South-Eastern Granada Basin, Spain. Engineering Geology, 50, 165-175. https://doi.org/10.1016/S0013-7952(98)00008-8

[19] Oster, J.D. and Shainberg, I. (2001) Soil Responses to Sodicity and Salinity: Challenges and Opportunities. Australian Journal of Soil Research, 39, 1219-1224. https://doi.org/10.1071/SR00051

[20] Halliwell, D.J., Barlow, K.M. and Nash, D.M. (2001) A Review of the Effects of Wastewater Sodium on Soil Physical Properties and Their Implications for Irrigation System. Australian Journal of Soil Research, 39, 1259-1267. https://doi.org/10.1071/SR00047

[21] Mandal, U.K., Bhardwaj, A.K., Warrington, D.N., Goldstein, D., Bartal, A. and Levy, G.J. (2007) Changes in Soil Hydraulic Conductivity, Runoff, and Soil Loss Due to Irrigation with Different Type of Saline-Sodic Water. Geoderma, 144, 509-516.

https://doi.org/10.1016/j.geoderma.2008.01.005 
[22] Ajwa, H.A. and Trout, T.J. (2006) Polyacrylamide and Water Quality Effects on Infiltration in Sandy Loam Soils. Soil Science Society of America Journal, 70, 643-650. https://doi.org/10.2136/sssaj2005.0079

[23] Schleiss, A.J., De Cesare, G. and Althaus, J.J. (2008) Reservoir Sedimentation and Sustainable Development. International Conference on Erosion, Transport and Deposition of Sediments, Lausanne, 23-28.

[24] Whitworth, T.M. and Ghazifard, A. (2009) Membrane Effects in Clay-Lined inward Gradient Landfills. Applied Clay Science, 43, 248-252. https://doi.org/10.1016/j.clay.2008.07.026

[25] Tekwa, I.J., Belel, M.D. and Alhassan, A.B. (2010) The Effective of Indigenous Soil Conservation Techniques on Sustainable Crop Production. Australian Journal of Agricultural Engineering, 1, 74-79.

[26] Mushir, A. and Kedru, S. (2012) Soil and Water Conservation Management through Indigenous and Traditional Practices in Ethiopia: A Case Study. Ethiopian Journal of Environmental Studies and Management, 5, 343-355.

[27] Abedini, A. and khani, M. (2011) The Study of the Role of Making Muddy the Water of Baladeh Aqueduct in Preventing Water Loss and Its Effects on the Quality of Soil, Water and Agricultural Products. International Conference on Traditional Knowledge on Management of Water Resources, Yazd.

[28] Mahdavi, M. (2007) Applied Hydrology. Vol. 2, 6th Edition, Tehran University, Tehran.

[29] Alizadeh, A. (2013) The Principles of Applied Hydrology. 36th Edition, Imam Reza (AS) University, Mashhad.

Submit or recommend next manuscript to SCIRP and we will provide best service for you:

Accepting pre-submission inquiries through Email, Facebook, LinkedIn, Twitter, etc. A wide selection of journals (inclusive of 9 subjects, more than 200 journals)

Providing 24-hour high-quality service

User-friendly online submission system

Fair and swift peer-review system

Efficient typesetting and proofreading procedure

Display of the result of downloads and visits, as well as the number of cited articles

Maximum dissemination of your research work

Submit your manuscript at: http://papersubmission.scirp.org/

Or contact cweee@scirp.org 